\title{
Comparing Islamic International Law and Contemporary International Law with an Emphasis on Identification Principle and Human Rights Principle
}

\author{
Alireza Azadikalkoshki*, Mohsen Hosseinabadi \\ FEBIT International Law Office, Istanbul, Turkey \\ Email: ^f.o.20@febitmail.com
}

How to cite this paper: Azadikalkoshki, A., \& Hosseinabadi, M. (2018). Comparing Islamic International Law and Contemporary International Law with an Emphasis on Identification Principle and Human Rights Principle. Open Journal of Political Science, 8, 139-151.

https://doi.org/10.4236/ojps.2018.82011

Received: November 15, 2017

Accepted: April 10, 2018

Published: April 13, 2018

Copyright $\odot 2018$ by authors and Scientific Research Publishing Inc. This work is licensed under the Creative Commons Attribution International License (CC BY 4.0).

http://creativecommons.org/licenses/by/4.0/

\begin{abstract}
The purpose of the Islamic International Law is the applicable rules of an international community in which both Muslim and non-Muslim countries are present. In many of its foreign relations, the Islamic country can follow the rules that come from the sources of public international law. Islamic International Law means the general rules governing the international relations of a Muslim country, which during the ten years of the political life of the great Prophet of Islam was developed in Medina and the first Islamic state was formed with the emigration of the Prophet (pbuh) to Medina. By contrast, contemporary international law takes into account any agreement that is being made between members of the international community and aims to create some legal effects. Because the issues of Islamic and contemporary international law are diverse and different, this article focuses on two components, the principle of identification and human rights. In contemporary international law, identification is an action taken by old governments to recognize a new government. Islam, in its relations with peoples and peoples, and the treaties it concluded with them, showed that the problem of identifying something is completely natural, but it is also absolutely necessary. Regarding human rights, both in Islamic law and contemporary international law, it has been tried to prevent it from being violated, with the difference that these two laws have minor differences in relation to human rights.
\end{abstract}

\section{Keywords}

International Law, Contemporary International Law, Recognition, Human Rights 


\section{Introduction}

The intellectual and ideological attributes are the most important element in the formation of a nation, and this is why this type of attribute has a significant effect on the distinction between countries, and it defines the boundaries between all countries. Countries get their names from political thought and beliefs before they become named in terms of climatic and geographical conditions or race. One of the bases for dividing political and intellectual flows into the Qur'an is the belief and unbelief of individuals and intellectual and political factions. In this division, humans are divided into believers, polytheists, hypocrites, unbelievers and apostates. Thus, the jurisprudents have referred to countries as "Dar" in terms of their position against Islam, and they set each Dar as the indicator of their people's ideological and political choices. "Dar" literally means home, which in this case represents the concept of the country. Although there is no Qur'anic documentary about dividing the world into Dar al-Islam and Dar al-Kofr, jurisprudents have been forced to explain the legal effects of these two regions on the basis of authentic Islamic narratives. However, some thinkers have believed that Roman or Greek thought was involved in this division (Khalilian, 1996: p. 105). The subject of Dar al-Islam and Dar al-Kofr and its scope and beyond is complex, extensive and specialized in Islamic international law, and has shaped different but relatively close perspectives among jurisprudents. This issue is defined in international law under the heading of country identification; In this context, identifying countries is defined only in two temporary and permanent forms and does not include any other state, but from the various opinions expressed in the Islamic jurists' opinions, it is believed that they also have a third state for the identification of the international states, which itself calls for a detailed and in-depth discussion. Islamic international law does not mean that international law governs only the international relations of Muslim countries. Rather, the purpose of this title is the same rules applicable in an international community in which both Muslim and non-Muslim countries are present and the Islamic state can, in many of its foreign relations, follow the rules, which have come from the sources of public international law. On the other hand, contemporary international law also has a specific definition of identification and its enforcement, which recognizes the identification as a legal practice by the old governments in the direction of the identification of a new government. Aside from the discussion, in this research, we pass on human rights in Islam and contemporary international law that despite some minor differences, both laws emphasize human dignity and human rights and non-violations of human rights, in line with fighting oppression and helping oppressed people.

\section{The Sources of Public International Law}

1) International treaties: Any agreement made between the members of the international community and aimed at creating some legal effects.

2) International custom: This means that in some cases, although countries 
have not written rules on a paper page, but in practice, they adhere to certain rules that their compliance with these rules is clearly implied from it. In terms of fundamental Islamic rules, there is also no obstacle that an Islamic state, in cases where it is allowed to conclude a treaty, can actually help to create an international custom.

3) The general principles of the law adopted by the civilized nations.

4) Judicial decisions and the opinions of the most prominent lawyers, as a means of determining legal rules.

Because in international Islamic law international rules are evaluated from the point of view of a particular legal system, then, its sources must also be learned.

\section{Here Are Two Main Sources}

1) The Quran book:

The Quran is the constitution and the axis of thought of the Islamic society and its miracles guarantee the survival of the Islam religion. Of the verses of the Holy Qur'an, about 500 verses are about practical laws and regulations.

2) Tradition:

It includes speech, deed, or confirmation of the Islam Prophet (PBUH). But Imams' jurists define the tradition in this way:

"Speech, deed or confirmation of infallibles. And they meant that in addition to the Prophet, the words and actions of the infallible Imams were also the source of law."

And two auxiliary sources:

1) Consensus: The consensus of the Islamic jurists in a legal issue.

2) Wisdom: The wisdom of Shiites and the analogy of Sunnis are sources that can be used to discover God's command. With the death of Prophet Muhammad (PBUH), the Islamic society inherited a legal system, which can be called the Islamic natural law (i.e., natural and divine). Islam claims that the drawing up of such a widespread legal system is not in the power of any authority other than the source of divine revelation. Therefore, the legal provisions of Islam have been communicated to us by the guidance of God (Heydari, 2010: pp. 25-33). The Status of International Law in the Legal System of Islam Are in Islam, "international law" and "domestic law" considered as independent legal systems, or a single system? If we accept the first one, we have come from the school of dualism, and if we consider them to be a single system, we would join the Monists. In addition, if domestic law and international law are considered one, another question arises; which of these two follows the other? If we understand the meaning of international law as "any binding rules that governs any international relations, then it includes any legal regulation governing any international relations"; namely, whether those rules have come from the domestic source of a country, or from the international treaty and custom. Whether it governs the relations between countries, or the relations between a person with an alien state, and even the relations of two individuals belonging to two different countries. In 
Islamic countries, there is no debate if the international rules are $100 \%$ based on the domestic rights of the Islamic state; because this category of regulations is an integral part of the legal system of Islam and there is no transposition for them. The rules are placed along one another and each is applicable in its place. If the provisions arise from the international treaty or custom, that is, the result of the Islamic state's relationship with other country or countries; On the one hand, the duelists consider international law and domestic law as two equal, independent and separate systems, that none of them is superior to the other, and it is not necessary that one be subordinate to another. Obviously, Islam is basically opposed to this thinking. Here, Islam takes a position of denial against the duelists, and is not symphonious to the followers of this school at all. On the other hand, the monists put international law and domestic law in the hierarchy, along each other, and know one of them as another follower. The governing spirit of this school is the same as paying attention to the necessities of social life as the basis of legal regulation (Same, 25-5).

\section{Islamic Global (International) Viewpoint to Law}

Islam wants to provide an interconnected nation and a human unity from humankind on the planet. That is, a country of latitude and longitude of all the planet and the state with the radius of activity and competence of all humans and territories. Accordingly, the legal system of Islam can be viewed from two perspectives:

1) Perfection (or what should be): Here, it is assumed that legal regulations should govern a society that is ideal of Islam and has been realized and fulfilled in the outside world.

2) The status quo (or the undeniable facts that are now): Given the current status of the world, and in conditions where unity and integrity still has not affected the human society, it is necessary to apply Islamic legal regulations in order to reflect on the current situation and to try to prepare the nature and mind of mankind by improving his thought in order to spread its universal system, in practice, throughout the universe. Therefore, with this view, it is necessary for the world with various languages, systems, customs and rules and regulations to be separated in a systematic and distinct way in the form of very large countries and territories with their own legal regulations, and the components of its nature are examined (http://www.Law88tehran.blogsky.com).

\section{The Rights and Duties of Muslims in Islamic Society}

Each Muslim, in a genuine Islamic society, will have the rights and duties as follows.

a) The right to freedom of action for the citizen: the freedom to action, here, takes into account the principle of Ebahe, whereby every Muslim grants himself the right to freedom of action in a wide area.

b) The right to protection of life and property: Basically, the consistency of the 
Islamic state depends on the defense and resistance to aggression and incursion.

c) Citizen's responsibility of the citizen against the group of citizens: Islam, besides the responsibility of the citizen against the group of citizens, also refers to the responsibility of every Muslim against the Muslim community.

d) Participation of all people in the political life of society: The criterion of excellence in Islamic society is virtue and piety. Therefore, even a person from the lowest social classes will be able to reach the highest political officials in society (in fact, meritocracy is desirable).

Therefore, we see that in Islam, all Muslim individuals enjoy the rights and benefits of citizenship, and these rights have been recognized by the founder of the Islamic state. One of the advantages that Islam has in this regard is that it was the founder of the rights of citizenship for fourteen centuries. Therefore, the Western claim that citizenship is the phenomenon of the $17^{\text {th }}$ and $18^{\text {th }}$ centuries is completely distant from reality and is not more than a bump (Heydari, 2010: pp. 5-25).

Sovereignty in Islamic international law and contemporary international law regarding sovereignty, there is a difference in insight between Islam and contemporary international law and it's that Islam recognizes the legitimacy of the political organization of a country that it intends to establish relations with it, which, of course, will be reflected in practice. However, contemporary international law places one's position on the situation as one of its legitimacy. However, contemporary international law considers only the establishment or domination on the situation as a measure of its legitimacy. In principle, the Islamic government is obliged to deal with a country that has been properly and legitimately represented by its people. However, contemporary international law establishes legal relationships with any forceful country that has dominated a country (Behzadi, 2005: p. 25).

\section{International Law and the Definition of Identification}

The definition of the International Law Institute of identification: "Identification is a practice by which the old governments confirm and validate the existence of a new and independent political community that is capable of observing international law and declare their will to recognize it as an international member". In other words, identification is "a country that certifies that the necessary elements for the creation of a country have been made for a specific human grouping, in practice or through a formal declaration" (Amid Zanjani, 1994: p. 23). From a practical and contemporary perspective, identifying governments in the international system is an action taken by the old governments to recognize a new government. As a result of this action, the new government can establish international relations in various fields, create and take on obligations with old governments.

Of course, this practice has traditionally been carried out in the international relations scene in the past, and has been practiced as a customary rule and grad- 
ually became a legal entity from the eighteenth century, especially since the independence of the United States. As we know, for the formation of the state, three factors are needed: population (nationality), land (geographic boundaries) and political power (sovereignty). So, with these three factors getting together, the new government actually exists and legitimates, which can be considered legal. But in general, identification is a political act, as the International Law Institute at the 1936 Summit, has identified recognition as a political action; In the international custom, identification is also known as a political process (ibid., 27).

Identifying governments from a contemporary perspective

Identification is one of the topics of international law that applies in two areas:

1) Creating a new government

2) The formation of a new government

New governments are independent political units that have recently appeared in the international community. These governments are generally created through national liberation movements or through the division of great empires. These states, on international scenes, are in need of recognition by other governments, but other governments are free to identify or not identify them.

\subsection{The Nature and Legal Effects of Identification}

There are two theories on whether the identification of governments and states would give them international character, or is it because these governments and states have already existed and the identification justifies and legitimizes them: The first theory, which is an establishing theory, recognizes the identification, the means of conferring an entity and international character to states and governments; In other words, this identification is the need to comment on the right of existence and the sovereignty of the new state. In this case, the new country will be qualified and will have independence as well as international legal character. The second theory is the declarative theory and recognizes the identification as a declaration of the existence of governments and states. That is, the old countries make declarative identification for the new country, no matter how it is created. In this case, they can establish a relationship with the new member, and this theory is accepted today. Of course, it is necessary to note that the establishment of such relationships does not need the identification, because, for example, for the affairs of the citizens, without identification, there can be relations of a consular type, and so, this does not mean the identification of that state. In any case, both in the declarative theory and in the establishing theory, the new government is known as a new member of the international community (http://www.Law88tehran.blogsky.com).

\subsection{The Terms of Government Identification}

1) Independence: the independence of a state is a fundamental condition for its identification by other states; For example, insurgent claims for the creation 
of a new government cannot be verified, because they must be independent of both the main government and other governments. For this reason, the independence of Syria and Palestine and Iraq from the Ottoman Empire did not cause them to be identified. Because, these lands were immediately controlled by other governments, France and Britain.

2) Internal Stability: In order to identify a new state, its internal stability is also taken into consideration, in which the strength of the new government and the people's trust in this government are significant; the United States did not recognize Cuba for this reason.

3) Certain Territory: The third most important element for identifying states is the certain land, which is under the control of the new government (Ibid, 29-5).

\subsection{The Types of Government Identification}

1) Explicit Identification: That is made explicitly and publicly by setting up a formal document, such as a specific declaration or treaty. This type of identification can be done individually or collectively (Al-Zahili, 1992: p. 153).

2) Implicit Identification: This kind of identification is done implicitly by establishing political and consular or diplomatic relations (Heydari, 2010: p. 20). The implicit identification can even be made by taking part in the sporting field; for this reason, athletes in our country are not willing to play matches with Israeli athletes. Because we have not recognized Israel, in fact, we have not identified it.

\section{The Identification of States}

Each government that is created has the right to form a state, and this state is the representative of that government in international relations. The change in the composition and form of states does not have any relation to the government and does not affect the international character of the government. For example, the replacement of the Republican state with the Democrat state in the United States, but in cases of coup and revolution in the states, the issue is different, and the identification of states in these cases arises.

\subsection{The Identification of Governments from the Viewpoint of Islam}

Islam in its relations with peoples, nations and foreign countries, and the treaties that it concluded with them, showed that the issue of identification is completely natural in its view, but it is also absolutely necessary. As mentioned in the discussion of nationality, in the conditions of that day and even today of the world, the plurality of nationalities as the necessities of human society has been acknowledged by Islam, in two directions: 1) In terms of this necessity, that human thought has not yet reached that stage of development, so that it can live in a single Ummah without any distinction. 2) In terms of difference and diversity, in 
many respects, from the point of view of creation and material and spiritual needs, as well as ethnic groups and human groups with beliefs, languages, rituals, customs, ... As many writers have often spoken about, Islam has urged the Islamic State to invite nations to Islam and monotheism and to form a united nation in external relations. Accordingly, a variety of views have been expressed in this regard (ibid, 25-5).

\subsection{The Types of Identification from the Perspective of Islam}

1) A legitimate and rightful power that is based on Islamic criteria. Like an Islamic state in another country, which is loyal to Islamic values and principles, and therefore can maintain the relationship of Islamic brotherhood with the intended country. In this case, the identification will take place, in the form of de jure, that is, both its existence and its legitimacy [Divine and legal (popular) legitimacy] is confirmed.

2) The desired power is legitimate, but in legal terms, in the sense that it is approved by the people, it is, therefore, a legal power. In this case, there is also identification, there is also the establishment of relations, but not to the depth and breadth of the above-mentioned countries. Of course, in these cases, Allah the Exalted in many verses has pointed out that the establishment of a relationship and the expression of friendship with foreign nations is permitted under Islamic law, provided that it does not lead to unpleasant consequences; Like, unilateral friendship, obedience to the aliens, propensity (feelings of confidence and support), selflessness and fascination, acceptance of the protectorship of infidels and ... (Legal legitimacy).

3) The evaluated country is a country where the ruling regime even lacks the same legitimate legitimacy. Therefore, it is not religiously and legally valid. That is, it has been unjustly imposed. Of course, such a state, from the point of view of international law, is identified as de jure because it has a legal status. However, the Islamic government does not recognize it. However, if necessary, the Islamic government will be allowed to identify the intended country. However, the identification of de facto rather than de jure, therefore, is very restrictive and prudent only on the necessity and within the framework of the prevailing emergency.

Of course, this type of identification differs from the perspective of contemporary international law and Islam, as follows:

a) The purpose and motive of the Islamic government is to eliminate a necessity, but the motivation of the nations of the world is the interest-seeking and the provision of benefits as much as possible, by any possible means.

b) The radius of relations in the Islamic government in this case is up to the boundary of necessity, and it does not continue, while in today's world, in order to be more prosperous, it is tried to develop and continue this relationship. Another division for identification in the international law of Islam is identification in times of peace and war that we omit from mentioning them in order to 
avoid the prolongation of the word (Amid Zanjani, 1994: p. 23). Human rights in Islamic international law and contemporary international law.

\section{Islam and Human Rights}

The Holy Qur'an has endeavored to protect human rights in several verses which we mention to a few cases:

(To those against whom war is made, permission is given (to fight), because they are wronged; - and verily, Allah is most powerful for their aid. (They are) those who have been expelled from their homes in defiance of right, - (for no cause) except that they say, "our Lord is Allah". Did not Allah check one set of people by means of another, there would surely have been pulled down monasteries, churches, synagogues, and mosques, in which the name of Allah is commemorated in abundant measure. Allah will certainly aid those who aid his (cause); - for verily Allah is full of Strength, Exalted in Might, (able to enforce His Will) (Hajj: 39 \& 40). This verse considers the cause of permission in Jihad to "be oppressed" and being expelled and displaced of believers from their homeland by oppressors.

(And whoever avenges himself after having been wronged-those have not upon them any cause [for blame]. The cause is only against the ones who wrong the people and tyrannize upon the earth without right. Those will have a painful punishment) (Shuraa: $41 \& 42$ ).

(And what is [the matter] with you that you fight not in the cause of Allah and [for] the oppressed among men, women, and children who say, "Our Lord, take us out of this city of oppressive people and appoint for us from Yourself a protector and appoint for us from Yourself a helper?"). (An-Nisa: 75). In the tradition of the Prophet (peace be upon him and his family) and the infallible Imams (PBUH), it has also been ordered a great deal; "In Islam, the responsibility to deal with threats and intimidation is a universal duty that everyone must stand firmly against the threats and intimidation and defend the oppressed and be the enemy of the oppressor." (Khosrawi, 1373: p. 69). As the commandment of Amir al-Mu'minin Ali ibn Abi Talib (PBUH) that "Be always the enemy of the oppressor and the helper of the oppressed" (Nahj al-Balaghah, letter 47) expresses the legal principles of Islam and the legitimacy of this legal system. In the narration of the Prophet Muhammad (PBUH \& HP), it has been narrated that the Prophet (pbuh) said: "If anyone hear the shouts of help of any oppressed (whether Muslim or non-Muslim) who seek Muslims help, but he does not answer his shout, he is not Muslim (Hurr Ameli, 11, Bita: 108). And in another narration he said: "Helping the weak is the best and most virtuous alms." (Ibid). According to some other traditions, Muslims must work on solving their problems and knotting each other and trying to do this, otherwise they are out of the real Muslim category (ibid, 108). In Sahih of Bukhari, it has also been narrated from the Prophet that he said: "All Muslims are brothers, they do not oppress each other, and they do not leave each other in front of their enemies and they 
do not abandon each other alone." (Amid Zanjani, 1994: p. 830). In the Mosnad of Ahmad ibn Hanbal, it has also been narrated from the Prophet that: "Anyone who a believer becomes degraded before him, but does not help him, while he is able to help him, Almighty God, on the Day of Judgment, before all the blessings will humiliate him." (Ibid, 84). The author of Fatah al-Barī writes in the description of Prophetic Hadith in defense of the oppressed: "Those who have the power to save the oppressed, it is necessary for him to repel oppression in any way possible, and his intention in defense is not to kill the cruel, but the purpose is to repel the tyranny, and if he defends, the cruel blood is wasteful, and it does not differ in defense of himself or in the other" (Ibid, 84-83). In addition, the practical tradition of the Prophet (SAW) in concluding defense treaties as a helping hand of the oppressed, as in Holf al-Fozool (Al-Zahili, 1992: p. 77), or as the "declaration of solidarity and mutual support", as it was done in the treaty with the "Bani Zomreh" (Amid Zanjani, 1994: p. 703), and "Khaza'a" (Ibn Hisham, Vol. 4, Bita: 31-46), is the evidence of this subject. In the treaty of the young men (Half al-Fozool), the participants, including the Prophet Muhammad (PBUH), swore to be "the united hand" with the oppressed and against the oppressor, so that the oppressor would pay the oppressed person, and this is a treaty that is kept as long as the sea wets its shore (that is, forever) (Amid Zanjani, 1994: pp. 720-719). In other words, Islam has not determined a specific place for defending the oppressed. Wherever oppression takes place, even within non-Islamic countries, jihad is legitimate to eliminate the oppression of Muslims or non-Muslims (Ibid, 591). Here, it is necessary to recall that the defense of the oppressed is not limited to the oppressed Muslims and their allies; as one of the legitimate defense cases of the jihad is to defend all oppressed and oppressed against the military invasion (Ibid, 718). If non-Muslim populations or states that are not parties to the Islamic government are subject to military oppression and rape, the Islamic government has the right to defend them. Of course, some scholars and jurists have skeptical about the legitimacy of such an action considering some reasons

\section{Contemporary International Law and Human Rights}

In contemporary international law, human rights are considered fundamental and non-transferable, which living, as human beings, is based on them (Behzadi, 2005: p. 227). Although the principle of non-interference in the internal affairs of states is not only recognized in the United Nations Charter, it is also "a part of customary international law and is based on respect for the territorial sovereignty of states" (Behzadi, 2005: p. 679). According to a ruling by the International Court of Justice on Nicaragua case, "the principle of non-intervention consists of choosing political, economic, social and cultural systems and regulating foreign policy" (Behzadi, 2005: p. 368). Every country is as it wants; but the point is, to what degree is the state sovereignty? Because, "although sometimes, the universal human rights are criticized and challenged, but the principle 
that human rights must be defended is, in our era, a clear and evident principle and accepted as a value and no one actually objects to the principle of the defense of human rights" (Khosrawi, 1373: p. 20). Is still, how the behavior of governments with their citizens, such as those that were thought to be in the pre-World War I era, an issue within the domestic jurisdiction of the state (Khosrawi, 1373: p. 65) that states and international organizations, even the United Nations, have been prohibited from intervening in, or that this right has been restricted by the development of human rights, and if governments or international organizations are allowed to interfere in some cases, to what extent is this permissible and can they resort to force and military action to protect human rights? Dr. Masayeli says: "The charter does not provide a list of human rights and fundamental freedoms, according to Prof. G. Tunkin, it considers the principle of respect for the fundamental human rights in international law, which imposes restrictions on state" (Masaeli, 1992: p. 167). Therefore, we are talking about the scope of the protection of human rights in contemporary international law. Given the growing importance of human rights, when a political system of dictatorship and repression has dominated the people and ignored their rights, can the armed attack and military operations be used as a "humanitarian intervention" to protect human rights and help those under oppression and strangulation? Because human rights in one direction are divided into two parts of individual rights (such as: the right to life, the right to security and freedom, etc.) and collective rights (such as: the right to self-determination, which is mainly demanded by militant groups and liberation movements). We continue our discussion on the two axes: 1. Humanitarian intervention in the form of the protection of individual rights, which, according to its purpose, is of two types: It is either focused on government structure and in order to restore democracy; Like what was said about the American intervention in Panama in December 1989 (Khalilian, 1996: p. 803). Or it focuses on rescuing individuals and preserving and defending the fundamental rights of citizens (Ibid, 802). As a result, both the legal systems of Islam and the contemporary international, typically, have unity of opinion in principle of the protection of human rights, and even beyond, in many respects, in generalities. Except for a few cases, in other cases, there is disagreement over the scope and basis of the rights or how to gain those rights, not in the principle of benefiting human beings from rights such as the right to liberty, the right to life, the prohibition of torture (Khalilian, 1996: p. 40) and personal, life, honor security, and so on, as in articles 18(a) and (b), as well as in Articles 20 and 22 of the Islamic Declaration of Human Rights it has been emphasized (Ibid, 40), and the violation of these rights has been denounced: "In the view of Islam, if a government deprives a group of human beings of its inherent natural right, it has committed a betrayal that is related to humanity" (Khalilian, 1996: p. 232). Thus both Islamic law and contemporary international law have been attempted to prevent its violation. At the same time, it should be noted that the process of protecting human rights in contemporary international 
law, which is predominantly Western, has a short history and It dates back to the late eighteenth century, i.e. 1789, when the first human rights declaration (after the French Revolution) was published in an introduction and in 17 articles; however, in Islamic law, at the very beginning of the Islamic government, the issue of protecting the rights of religious minorities as well as of all human beings has been raised and their rights have been emphasized. It also shows the transcendence of international law in its evolution towards nature and divine rights, in addition to the fact that even the very same Declaration of Human Rights is fundamentally due to the efforts of the Prophets (AS) (Masaeli, 1992: pp. 230-229). Also, according to the investigation of the late Allamah Tabatabai, Cyrus, the same Zulu-Qarenin was one of the divine men, who, in $560 \mathrm{BC}$, proclaimed decrees or charter that included rights and freedoms for mankind (Masaeli, 1992: pp. 425-407). Despite the unanimity of the two legal systems, in the principle of the protection of human rights, they disagree on how to support them and thus the legitimacy of the use of force for this purpose.

\section{Conclusion}

Not only has Islam made innovations in the field of international relations, but also it is the first coherent legal system in the world that has presented the idea of a complete identification (de jure) to foreign political societies. Islam has guaranteed the rights of the foreign nations on the basis of sacred commitment both during peacetime and during wartime. By studying the political dynasties of the Prophet of Islam, we can see a principle in his lifetime: "Man is a brother of man, believer or infidels, except what came out with evidence".

In this paper, we concluded that identification, from the point of view of Islam, is a completely natural and maybe necessary thing, and in answer to this question, "considering the purpose of Islam to eliminate blasphemy from the scene of the world, is identification, not in conflict with the ideal of Islam?" We said that Islam is a realistic school and cannot ignore the realities of the world. Because Islam does not want to deny the realities of the international community and live in isolation and seclusion, it will inevitably lead to the identification of foreign countries and nations. However, the identification of Islamic government in the face of international identification is a de facto identification, which is very restrictive and prudent only in the framework of an emergency, according to Islamic law. International impacts on this identification can be considered constant as long as the need is resolved. Therefore, very limited and cautious relationships are established, observing no loss and harm to the Muslims. While, in contemporary international law, identification, in general, notwithstanding the urgency and precaution of Islamic international law, is an act that is being undertaken by the old governments in order to recognize a new government. As regards as the human rights component, we also concluded that both the legal systems of Islam and the contemporary international, typically, have unity of opinion in principle of the protection of human rights, and even beyond, in 
many respects, in generalities. Except for a few cases, in other cases, there is disagreement over the scope and basis of the rights or how to gain those rights, not in the principle of benefiting human beings from rights such as the right to liberty, the right to life, the prohibition of torture and so on. Thus, both Islamic law and contemporary international law have been attempted to prevent its violation.

\section{References}

Al-Zahili, W. (1992). Asar Al-Harba al-Feghh al-Islami (4th ed.). Damascus: Dar al-Fekr. Amid Zanjani, A. (1994). Political Jurisprudence, Volume 3. Tehran: Amirkabir.

Behzadi, H. (2005). Principles of International Relations and Its Developments in Islam. Journal of the Faculty of Law, Tehran University, 12.

Heydari, H. (2009-2010). Identification from the Viewpoint of Islam and Comparing It with Contemporary View. University of Tehran, Booklet of the International Law of Islam.

Khalilian, K. (1996). Islamic International Law (5th ed.). Tehran: Islamic Culture Publishing House.

Khosrawi, A. A. (1373). The International Law of Legitimate Defense. Tehran: Adina.

Masaeli, M. (1992). New Generation of Human Rights, Foreign Policy Magazine. Tehran: Department of Political and International Studies of the Ministry of Foreign Affairs, No. 1. 